\title{
EDITORIAL
}

\section{SMÖRGASBORD OF EUROPEAN TELEVISION}

As VIEW enters its tenth year of publication, we present our first open issue. VIEW has always published theme issues, but the journal has also received some excellent submissions outside its specialized calls for papers. As a result, the editors decided to issue an open call for papers for the first issue of the tenth volume of the journal.

The resulting collection of articles represents a varied smörgåsbord of European television, covering television in Germany, Greece, Hungary, Malta, Russia, Spain, Sweden and Turkey. Moreover, many articles discuss the transnational movement of television: a Turkish adaptation of a Danish series, the Portuguese framing of a Spanish historical series, East German films on Swedish television, Russian television programmes on the international market.

If we view the results of the open call as an indication of the current methodological emphases of scholars working on European television, two approaches seem most popular. Firstly, articles based on textual analysis of television programmes analyse the narration and aesthetics in television programmes, from 1950s television news (Lehnert) to contemporary series (Batori, Kesirli Unur), as well as issues on representation, focusing in particular on gender and sexuality (Chairetis, Evenden-Kenyon). A second group of articles uses historical methods and archive sources to explore television's past (Lehnert, Rajcsányi, Stjernholm). In addition, there is work in the fields of media industry studies (Brassard, Kesirli Unur) and education (Cutajar). A conspicuous absence is audience studies, perhaps reflecting a wider trend in television studies. ${ }^{1}$

Several articles reveal hidden histories. Spyridon Chairetis argues persuasively for close textual analysis to discover in Greek television comedies depictions of lesbian characters which are not labelled as such. Even recently, the word 'lesbian' itself has been bleeped out from rebroadcast comedies, and scenes in imported US shows have been cut. Nevertheless, as Chairetis shows, the characterisation has remained and can be read. Similarly, Anna Batori reveals how the German Netflix series Dark (2017-2020) uses its 'complex' television narration to engage with Germany's past in ways that would escape an international audience. While Dark was made for a global audience, Batori argues that it engages with German history, for instance, by evoking Nazi crimes and significant periods in German history. Batori then reads Dark as an expression of a crisis of national memory in Germany. The series' cyclical conception of time suggests that there is no easy escape from the horrors of the past. Instead of nostalgia, Dark offers a kind of anti-Heimat vision of Germany's past.

Péter Rajcsányi presents detailed research into the hard-to-access paper archives of Hungary to reveal how the project to set up a television service in the early 1950 s fell victim to the power struggles going on within the 
Hungarian government and Communist Party which culminated in the uprising of 1956. All the usual problems of early television (underfunding, choices of technology, arguments about content) are coloured by the more general struggles taking place against the backdrop of the destalinisation of the USSR. Cold War attitudes also significantly impeded the technological development of Hungarian television, even though some equipment was eventually imported from the West.

Two seismic European events took place late in 1956. On 23 October, the Hungarian people rose up against the domination of the Soviet Union whose impact on the development of television has been painstakingly charted by Péter Rajcsányi. State security police fired on demonstrators from the radio building. At exactly the same time, France and the UK were planning to seize the Suez Canal from Nasser's Egypt, which had nationalised it earlier in the year. Their ill-advised invasion took place on 5 November. These were both major news events, needing to be covered by the young television services of Europe. Sigrun Lehnert shows how West German television covered the Suez Crisis. Despite (or perhaps because of) the continuing substantial military presence of France and the UK in West Germany, television news was slow to grasp the significance of the events. It initially took its footage from traditional newsreel sources, just as most existing European TV broadcasters were doing. As the Suez crisis developed, TV quickly adopted its own style of coverage. This fuels the argument that the birth of TV news in Europe can really be dated from this crucial moment in European history in late 1956.

Exploring another aspect of Cold War era television history, Emil Stjernholm studies how and why the Swedish public service broadcaster Sveriges Radio (SR) imported films from the German Democratic Republic (GDR). In the context of Cold War era cultural diplomacy, Sweden was a key country (Schwerpunktsland) for East German propaganda efforts. Stjernholm focuses on SR's motives for importing films from the GDR and the films' reception in the Swedish press. SR's film policy emphasised the value of diversity and the need to combat Americanization; Eastern European films fit the 'radical' profile of the newly installed TV2 particularly well. While propagandistic East German films caused some controversy in the press, children's programmes and documentaries about Chile and Vietnam were more positively received.

Different interpretations of European history still play themselves out in TV depictions of remote historical characters in contemporary television fiction. Elizabeth Evenden-Kenyon studies the representation of Mary I (1516-1558), queen of England and wife of Philip II of Spain, in the Spanish series Carlos, Rey Emperador (TVE, 2015-2016). As background, Evenden-Kenyon traces how portrayals of Mary have developed in English-language historiography, where she has been fixed with the epithet 'Bloody Mary' from the Victorian era onwards. In contrast, Carlos, Rey Emperador follows trends in recent Spanish historiography, where the previously negative view of Mary has made way to a more sympathetic assessment. Departing from traditional representations of Mary, the series and its supporting Spanish and Portuguese online material represent Mary as an attractive woman worthy of the viewers' empathy.

To complete this issue's consideration of television and history, Alexander Cutajar explores the value of television online archives in the history classroom. Based on a study of Maltese secondary school students, the article considers how clips of old television programmes can be used not merely to illustrate the past but to help students to adopt an analytical approach to media content and to understand history as a discipline. The article offers practical suggestions for teachers on how to choose suitable audiovisual content for educational purposes and how to best make use of it; for example, how the teacher can facilitate class discussion in a way that helps students to consider key issues of history as a discipline, such as reliability of sources, interpretation, and continuity and change.

Both Jeffrey Brassard and Ayşegül Kesirli Unur present studies of contemporary television production, and both examine questions of failure. Failed productions and failed initiatives often provide rich material for researchers seeking to understand the hidden dynamics of television creativity and marketing. These two articles are fascinating contributions to this emerging trend. Brassard asks why Russian TV drama is not exported more widely when so much contemporary TV drama finds outlets in many national markets. He finds his answer in the particular characteristics of Russian TV fiction and compares its lack of success with the widespread acceptance of Russian animation on the global TV market. 
Ayşegül Kesirli Unur focuses on a case of a 'failed' television production, studying the Turkish series Cinayet (2014), an adaptation of the highly successful Danish police drama Forbrydelsen (2007-2012) that was cancelled after only five episodes. The article extends Joseph D. Straubhaar's influential concept 'cultural proximity' to consider how the lack of 'aesthetic proximity' hinders a television format's ability to travel successfully. The melodramatic and expressive style favoured in Turkish television series contrasts with the aesthetics of Nordic Noir, characterized by muted visuals and understated acting. Through comparative analysis of key scenes in the Turkish and Danish series, Unur shows how Cinayet struggles to adapt the atmosphere of the original story in a way that would work for Turkish audiences.

The authors of this issue have worked under challenging conditions during the covid-19 pandemic. Along its momentous effect on everyday life and the motivation to write, the pandemic has also made research more difficult, for instance through restricted access to archive material. We thank the authors and reviewers for their contribution to VIEW. In particular, we also thank Liam Wylie and Rieke Böhling who were part of the editorial team in the early stages of the issue.

\section{Mari Pajala and John Ellis}

\section{Note}

1. Graeme Turner, "Approaching Cultures of Use: Netflix, Disruption, and the Audience," Critical Studies in Television: The International Journal of Television Studies 14, no. 2 (2019): 222-232. 